\title{
INWARD HOUSE THERAPEUTIC COMMUNITY: 25 YEARS OF PROGRESS AND EXPANSION
}

\author{
DM Elliott, Trustee and Medical Officer \\ General Practitioner, Queen Square, Lancaster
}

When Walter Lyon, a Lancaster-based doctor, travelled to New York in the early 1970s he could not have envisaged the impact his trip would have on the victims of drug addiction throughout Lancashire. The original purpose of his visit was to explore employment opportunities. Formerly an orthopaedic surgeon in the army, he was seeking a change in direction - a new challenge. On arrival in New York he immediately became aware of the enormity of the narcotic drug problem on the streets of the city and was motivated to involve himself in this field. He soon forged a friendship with two local drug workers and together they persuaded a city centre hospital to set up a 'therapeutic community'(1). This treatment model was increasingly commonplace in the USA at the time.

The Rehabilitation Unit slowly became established but the trend at that time was for community-based units and it was therefore relocated to the notorious Bronx area and a second site was set up outside the city in the Liberty district. Dr Lyon and his co-workers were proactive in seeking drug addicts from the streets and inviting them to the community. The project was named Inward House Therapeutic Community (New York).

The future of the community was secure and after two to three years Dr Lyon returned to the UK. Back in his native Lancaster he took up a position as a clinical assistant in psychiatry at Lancaster Moor Hospital. In his work on the wards he came across many drug addicts and became increasingly concerned about the paucity of local drug services and the apparent lack of government policy to deal with this escalating problem.

In 1978, mindful of his work in New York, he purchased 89 King Street, a large terraced house in the middle of the city. It was to become a rehabilitation unit and the plaque outside bore the name 'Inward House Therapeutic Community (Lancaster) ${ }^{\text {(1). }}$.

\section{THERAPEUTIC COMMUNITIES: HISTORICAL PERSPECTIVE ${ }^{(1)}$}

The establishment of the first therapeutic community is commonly attributed to Charles Dederich, an unemployed oil executive and an ex-alcoholic, who was an active member of Alcoholics Anonymous. He was searching for a different approach to the treatment of addiction and founded Syanon in 1958 in California. This was a residential community in which drug addicts and alcoholics could co-exist and help each other to remain 'clean' (a term synonymous with the phrase drugfree).
Syanon was run by addicts for ex-addicts, ie professionals were invariably excluded. Within the community a residential hierarchy was established. Rules were created and strictly followed. Failure to comply resulted in confrontation in encounter groups and often disciplinary action. This was the American model.

In fact the term 'therapeutic community' was originally coined in England by the psychiatrist Tom Main 12 years earlier in 1946. At that time he used the term in a general way to refer to any residential establishment that attempted to improve the quality of life of the occupants and included 'mental hospitals'. These formerly regulated institutions were responding to a climate of change signalled by a more democratic and liberal/caring approach. In England the development of the therapeutic community proper was influenced by the work of Maxwell Jones at the Henderson Hospital. The hallmark of these communities was the dissolution of the hierarchical arrangement so that power was shared. Decisions were made collectively in the community about the organisation and the treatment of the clients. This was in sharp contrast to the approach that was to develop across the Atlantic. Despite the fundamental differences between these two approaches they both shared the same umbrella term 'therapeutic community'. Other common features included:

- an informal and communal ambience

- group meetings to promote the therapeutic programme and discuss organisational policy. Information exchange was optimised and a sense of cohesion between residents was promoted. Decision-making became more transparent and democratic, in contrast to the old institutional regimes where policies were imposed and residents felt disempowered

- opportunities for interaction and personal feedback in order to modify dysfunctional behaviour of individuals within the community. This was more than personal feedback, however, and could involve the brokering of a contract

- sharing of maintenance tasks within the community.

Other more specific modes of therapy could be used to facilitate group work including psychodrama, cognitive behavioural therapy, art therapy and group analytical therapy.

\section{SYANON AND THE GROWTH OF 'CONCEPT- BASED' THERAPEUTIC COMMUNITIES}

Syanon was the first of the so-called concept-based therapeutic communities and it is on this model that Inward House has based its rehabilitation programme. Charles 
Dederich started discussion groups initially in his own apartment with other members of AA. These were lively meetings with no particular agenda, which Dederich described as 'free association' meetings.

The meetings increased in frequency up to three nights a week and became popular with both ex-alcoholics and an increasing number of ex-drug addicts. At an early stage Dederich invited a particularly needy addict to move in and he quickly overcame his habit. Dederich realised at this stage the potential benefit of residential treatment. Unfortunately a rift began to develop between the alcoholics and the drug addicts and thereafter Syanon concentrated on the rehabilitation of former drug misusers.

Dederich quickly registered his 'club' as a non-profit making organisation - the Syanon Foundation - and began to formulate the principles underlying his new movement, which he likened to the model of a family run on autocratic lines under the guardianship of the director. Within this family structure in an optimal environment the addict would feel secure.

A routine began to develop at Syanon that would underpin the rehabilitation programmes of most concept-based therapeutic communities in the future, including Inward House. This routine included daily job assignments, regular group therapy sessions and discussion around philosophical concepts. Around 1959, the community tightened the rules and insisted on residents being completely abstinent. Those drug-free residents who were progressing through the programme were regarded as role models for newer residents and, using the family model, were likened to older siblings.

Eighteen months after its establishment Syanon, with its 30 residents, moved to a wealthy suburb in Los Angeles and after a three-year legal battle with hostile local residents became officially approved. New communities were started in California and Nevada. Ex-residents formed groups supporting drug addicts within the prison setting (cf Inward House). In New York the problems of drug addiction were reaching alarming proportions and Syanon satellites expanded rapidly including the first community, Daytop Village. In 1968, another major organisation, Phoenix House, was founded, aided by ex-staff from Syanon.

It was only a question of time before this now successful model of rehabilitation was to spread internationally. In 1970 , three graduates from Phoenix House in New York arrived in Britain, at about the time when Walter Lyon was crossing the Atlantic in the opposite direction in his quest for a new career. Concept-based houses were set up in Oxford, Portsmouth, Sheffield and Dublin. Communities were also established in many European countries, notably Holland, Sweden and West Germany and, in subsequent years, in a further 60 countries.

\section{THE END OF SYANON}

It is ironic that the pioneer of concept-based therapeutic communities, Charles Dederich, who was acknowledged worldwide, would eventually lead his followers into obscurity.

Dederich's philosophical lifestyle had become widely respected and 'Syanon City' began to attract non-addicts as well as ex-drug addicts. Dederich himself became increasingly introverted and dictatorial. Syanon began to develop religious overtones and became intolerant of any opposing viewpoint. Finally, Dederich was arrested, along with many of his followers, on charges of conspiracy in 1978.

\section{INWARD HOUSE THERAPEUTIC COMMUNITY, LANCASTER ${ }^{(2)}$}

In 1979, shortly after my appointment as a general practitioner at Queen Square, Lancaster, I was approached informally by Walter Lyon to become the Medical Officer for Inward House - as a new enthusiastic principal, this was a task which I felt very willing to undertake. At that time the community was in its infancy with only two clients. The very first client, Kevin, still lives locally and has worked for the organisation for many years. At the start of the project there were only two staff: Tony and Maggie Lamb, both well-known personalities in the local mental health service, who had been befriended by Dr Lyon and were also motivated by the plight of drug addicts. They worked in a part-time capacity, living in a flat on the top floor of 89 King Street. In those early days group sessions would occur in the evening, occasionally extending into the small hours, facilitated by staff, including Dr Lyon. These meetings were very reminiscent of those held by Dederich in the early years at Syanon.

The number of clients at Inward House increased as its reputation developed. In the late 1980s the opportunity arose to purchase Highfield View, a much larger, detached Victorian building, which enabled the capacity to increase to nearly thirty. For a time, however, the project faltered and its whole existence was threatened by a change in funding arrangements. During this difficult period a new management structure was introduced under the chairmanship of Mike Jones, who has been associated with the project for 22 years. New ambitious plans were put forward to expand the project into East Lancashire. Dr Lyon, as a trustee and member of the management committee, was always a prominent figure in the planning process. More recently the project has acquired a property on Aldcliffe Road in Lancaster, which has enabled the community to provide a residential facility for mothers who require help and which also accommodates their children for weekend visits. Meanwhile the administration was rapidly expanding and has recently moved to spacious offices at Falcon House on Queen Square, which is now the headquarters for the project and provides invaluable space for the structured day programmes.

\section{INWARD HOUSE PROJECTS}

This is the collective name for the residential and communitybased units for drug users, which are now spread out across Lancashire. It is a registered charity and from the modest beginnings already described it has developed to become one of the major voluntary sector drug service providers in the northwest. Diversification over the last 10 years has given rise to services which include assessment, residential rehabilitation, full aftercare provision, supported housing, prison rehabilitation training, education and probation support. Services are provided in partnership with a range of voluntary and statutory drug services, the criminal justice system, and health and housing providers.

\section{The residential programme}

This can now accommodate 34 clients at any one time and is committed to provide a safe environment for clients who must adhere to three basis rules:

\section{- drugs and alcohol prohibited}

- violence or threats of violence not tolerated

- stealing not tolerated. 
Contravention of these rules can result in expulsion from the community.

Clients can be referred by a representative such as a probation officer, social worker, GP, drug worker, family member or the individual him/her self. Referrals can occur as a condition of bail, which is often subsequently changed to a probation order, which necessitates completion of the rehabilitation programme.

Residents feel secure in the environment, enabling them to increase their self-confidence whilst simultaneously bonding with their fellow residents based on the common goal of abstinence from substance misuse. This leads to a change in self-perception and a change in the way they perceive other people. Difficult or anti-social behaviour is challenged and may result in sanctions such as extra washing or gardening duties.

The treatment programme is an empowering process, which emphasises the importance of self-help and the ability to overcome the adverse factors which perhaps led to addiction. In order to accomplish this and sustain abstinence the clients must establish new values, learn to accept responsibility for their actions and develop a network of support from new friendships with other clients and staff.

Prior to admission the clients are assessed by the admissions coordinator. They must then secure funding from their local authority, often in the northwest, by means of a social work assessment. Once admission is organised the resident, on arrival, is allocated a keyworker who draws up a formal care plan following an initial body search to ensure that no drugs have been concealed.

The programme will vary in length from individual to individual depending on progress but usually will be between nine and twelve months.

As in other concept-based houses the programme is hierarchical:

1) Orientation - this is a critical time for new residents who are helped to settle in by fellow clients. Orienteers have one-to-one sessions with their keyworkers, who explain the philosophy of the house and encourage self-confidence and personal development. Regular seminars and group discussions will follow.

2) Level 1 (10 weeks-5 months). When residents are able to demonstrate an understanding of the principles underlying the treatment programme they move to Level 1, which entails greater responsibilities. They are expected to take a lead and act as a role model for newer residents. At this stage, residents make an objective assessment about their attainment level in the programme which, if satisfactory, enhances self-esteem.

3) Level 2 (5-9 months). Residents move to Level 2 when they feel they have achieved their personal objectives set in Level 1. In this period of the programme they plan careful strategies aimed at maintaining a responsible and abstinent lifestyle. They must also serve satisfactorily in the more senior posts within the community.

4) Level 3. This is the final step before returning to life in the community. The residents must formally apply to leave, and satisfy staff and fellow residents that they are psychologically prepared to return to an independent existence. In demonstrating this ability they work alongside staff as fellow members for a period of two weeks. An aftercare worker is allocated with a view to gaining fulltime employment and finding suitable accommodation. Once these goals have been achieved the resident graduates from the community following a formal ceremony.

Inward House recognises that relationships with families are often more difficult as a result of drug addiction. An important aspect of rehabilitation is rebuilding those relationships to regain trust and support and this will often enhance the possibility of a positive outcome following the rehabilitation programme. Family visits are therefore encouraged throughout the programme but contact is restricted to telephone calls during orientation.

\section{Funding}

The principle source is the weekly fee charged to residents, which is paid by the local authority. Residents are legally required to make a contribution to their fees from their sickness benefit. Inward House is a non-profit making organisation.

As already mentioned, in addition to the residential project Inward House has diversified into different areas including:

\section{1) The aftercare service}

This service was developed to assist residents who have completed the rehab programme and for ex-addicts leaving custody. The following issues are addressed:

- relapse prevention

- alcohol counselling

- employment, education and training

- housing and accommodation

- criminal justice system

- welfare rights

- relationships

- leisure activities

The service acknowledges the vulnerability of the client to relapse and provides suitable early intervention in this eventuality. The service is provided throughout Lancaster, Morecambe and East Lancashire and is commissioned by Lancashire Drug Action Team (DAT).

\section{2) Supported housing}

Supported housing units are available in Lancaster, Morecambe and East Lancashire in association with North British Housing Association. Secure temporary housing is provided for up to 12 months and referrals are made by the aftercare service, which also supports the tenants in securing more permanent housing arrangements.

\section{3) Options project}

This project was initially developed to ensure that Pendle's ethnic minority community were aware of the substance misuse facilities available, eg structured day programmes. It also aims to enhance communication with multi-cultural communities.

\section{4) Probation support services}

This runs in partnership with Lancashire Probation Service. The aim is to assist offenders with a history of drug misuse to minimise probation breaches and ensure that probation orders are completed with the ultimate aim of reducing re-offending. 


\section{5) Prison rehabilitation}

Inward House employs three prison link workers across Lancashire. Their role is to link offenders leaving prison with the relevant Inward House community services (eg supported housing) with a view to reducing substance misuse relapse. A 12-step drug rehab programme is also provided in HMP Lancaster Castle in partnership with the Prison Service.

\section{6) Structured day programmes}

Inward House provides structured day programmes across Lancashire. The project accepts referrals from stabilised drug misusers and those who have achieved drug-free status. In conjunction with local adult colleges and Lancaster Probation Service, basic skills are provided as part of the core curriculum. The aim is to prepare clients with the skills necessary to gain and sustain employment. The process helps to increase self-esteem and enhance communication and management skills.

\section{THERAPEUTIC COMMUNITIES - A NATIONAL PICTURE ${ }^{(3,4)}$}

There are currently 100 residential services listed throughout England and Wales. As well as concept-based houses, exemplified by the Inward House residential unit, there are 12-step houses based on Alcoholics Anonymous and a range of Christian, Buddhist and other religious communities which provide services with a focus on community living, counselling and general development. The Standing Conference on Drug Abuse (SCODA) seeks to reduce the harmful effects of drug use through informed debate. It is an independent organisation providing a voice for drug services including a comprehensive guide which lists all the rehabilitation houses in England and Wales.

\section{INWARD HOUSE SCREENING FOR BLOOD-BORNE VIRUSES}

Following the HIV epidemic in the 1970s, and the discovery of Hepatitis C virus in 1989, it seemed appropriate, in the early 1990 s, to introduce a screening programme for bloodborne viruses. The tests are not compulsory and are carried out after three months, to allow for seroconversion. Clients undergo pre-test counselling so that they fully understand the implications of the investigations. Results are conveyed to the clients at a follow-up appointment and vaccination against Hepatitis A and B is encouraged. In the event of positive tests (eg Hepatitis C) referrals are made locally to the department of gastroenterology.

\section{INWARD HOUSE AUDIT}

In February 2003, I carried out a brief audit of all clients who passed through the programme in the two-year period from January 2001 to December 2002.

\begin{tabular}{|l|c|c|c|}
\hline TOTAL NUMBER OF CLIENTS & & 138 & $\%$ \\
\hline MALE & & 103 & 74.6 \\
\hline FEMALE & & 35 & 25.4 \\
\hline AGE DISTRIBUTION & $20-25$ & 57 & 42.9 \\
& $25-30$ & 46 & 34.6 \\
& $30-35$ & 20 & 15.0 \\
& $35-40$ & 8 & 6.0 \\
& $40-45$ & 1 & 0.75 \\
& 45 & 1 & 0.75 \\
\hline \multirow{2}{*}{ RESIDENT } & $>12 / 12$ & 6 & 4.4 \\
& $9-12 / 12$ & 20 & 14.4 \\
& $6-9 / 12$ & 18 & 13.0 \\
& $3-6 / 12$ & 17 & 12.3 \\
& $1 / 52-3 / 12$ & 38 & 27.5 \\
& $<1 / 52$ & 39 & 28.3 \\
\hline
\end{tabular}

Of the 56 who registered with the Queen Square practice (after approx 3/12)

\begin{tabular}{|l|l|c|c|}
\hline WHERE NOW? & $\begin{array}{l}\text { INWARD } \\
\text { HOUSE } \\
\text { ie still in programme }\end{array}$ & 13 & 22.0 \\
\hline & $\begin{array}{l}\text { LANCASTER } \\
\text { ENVIRONS }\end{array}$ & 21 & 38.0 \\
\hline & $\begin{array}{l}\text { ELSEWHERE } \\
\text { IN UK }\end{array}$ & 22 & 40.0 \\
\hline $\begin{array}{l}\text { OFFERED } \\
\text { SCREENING }\end{array}$ & & 56 & 100.0 \\
\hline $\begin{array}{l}\text { ULTIMATELY } \\
\text { SCREENED }\end{array}$ & & 43 & 76.8 \\
\hline $\begin{array}{l}\text { DECLINED } \\
\text { SCREENING }\end{array}$ & & 7 & 12.5 \\
\hline $\begin{array}{l}\text { UNSUCCESSFUL } \\
\text { VENIPUNCTURE }\end{array}$ & & 2 & 3.6 \\
\hline DNA & & 3 & 5.4 \\
\hline $\begin{array}{l}\text { AWAITING } \\
\text { SCREENING }\end{array}$ & & 1 & 1.8 \\
\hline $\begin{array}{l}\text { KNOWN TO } \\
\text { HAVE } \\
\text { RELAPSED }\end{array}$ & & 15 & 26.8 \\
\hline $\begin{array}{l}\text { NUMBER } \\
\text { VACCINATED } \\
\text { (HEP A \& HEP B) }\end{array}$ & & & 10.7 \\
\hline
\end{tabular}

Of the 43 patients screened

\begin{tabular}{|l|c|c|c|}
\hline PREVIOUS & & 4 & 7.1 \\
\hline HEPATITIS B & & 15 & 26.8 \\
\hline HEPATITIS C +ve & & 1 & 1.7 \\
\hline $\begin{array}{l}\text { HEPATITIS C } \\
\text { INDETERMINATE }\end{array}$ & & 1.7 \\
\hline
\end{tabular}

Of the 15 Hepatitis $C+v e$ patients

\begin{tabular}{|l|c|c|c|}
\hline $\begin{array}{l}\text { REFERRED TO } \\
\text { HEPATOLOGIST }\end{array}$ & & 14 & 93.3 \\
\hline $\begin{array}{l}\text { LEFT BEFORE } \\
\text { REFERRAL }\end{array}$ & & 1 & 6.7 \\
\hline
\end{tabular}

Of the 14 patients referred with Hepatitis C

\begin{tabular}{|l|l|c|c|}
\hline DNA & & 6 & 40.0 \\
\hline $\begin{array}{l}\text { PCR +ve } \\
\text { (active viraemia) }\end{array}$ & & 9 & 64.0 \\
\hline PCR -ve & & 5 & 36.0 \\
\hline
\end{tabular}


Of the 9 Hepatitis C PCR +ve patients

\begin{tabular}{|l|c|c|c|}
\hline $\begin{array}{l}\text { REFERRED TO } \\
\text { HEPATOLOGIST }\end{array}$ & & 9 & 100.0 \\
\hline DNA & & 2 & 18.0 \\
\hline
\end{tabular}

1 patient cleared spontaneously

1 patient cleared following interferon and ribaviron

1 patient currently receiving treatment

1 patient awaiting treatment (following liver biopsy)

1 patient not needing treatment (favourable histology after biopsy)

1 patient awaiting liver biopsy

1 patient awaiting appointment with hepatologist

\section{Audit summary}

1 Predominantly male clientele (3:1), age 20-30 (78\%)

2 High drop-out rate in first three months in common with most communities, but staff are continually addressing this issue

3 All residents who ultimately became fully registered with the practice were offered screening. $76.8 \%$ were ultimately screened, of which $26.8 \%$ were Hepatitis C+ve (cf nationally quoted figures of $30 \%$, but could be as high as $50-80 \%)^{(5)}$

4 Of those Hepatitis C +ve patients, $64 \%$ were PCR +ve (cf nationally quoted figures of $75-80 \%)^{(5)}$

5 Only $26.8 \%$ of registered patients vaccinated - we have since introduced a more robust system for encouraging Hepatitis $A$ and $B$ vaccination.

\section{THE FUTURE}

The management committee meets on a regular basis and is continually striving to maintain high standards in all the projects throughout Lancashire. It is currently looking carefully at the topic of governance and other issues. Further expansion with structured daycare and housing units is taking place in other areas across Lancashire and we are currently considering the feasibility of introducing a detoxification programme prior to entry to the residential unit.

\section{A TRIBUTE}

On 24 October 2003 Inward House celebrated its 25th anniversary with a major function at Falcon House. One man was conspicuous by his absence - Walter Lyon.

One month earlier on 26 September 2003, Dr Lyon visited Highfield View at 8.00am as he had done habitually for nearly 25 years. He spent two hours as usual with staff and residents discussing the day-to-day problems. He then returned alone to his beloved Stanley Farm where he died peacefully but unexpectediy.

This article provides a timely opportunity to pay tribute to Dr Lyon, an affable, modest, immensely private man who was a friend and valued colleague. In recognition of his enormous contribution to Inward House the main residential unit (Highfield View) is to be renamed Walter Lyon House.

\section{REFERENCES}

1 Kennard D. Introduction to Therapeutic Communities. 2nd edition. Jessica Kingsley, 2000

2 Inward House Projects - Residential and Community-Based Rehabilitation for Drug Misusers. Available from Inward House Projects, Falcon House, Queen Square, Lancaster

3 Residential Drug Services - A Comprehensive Guide to Rehabilitation in England and Wales. 2nd Edition. SCODA, 1999

4 Department of Health, Drug Misuse and Dependence Guidelines on Clinical Management. TSU, Department of Health, 1999

5 Unlimited anonymous surveys Steering Group 2001 Prevalence of HIV and Hepatitis infection in UK. Department of Health, 2001

\section{MBMJ Editor}

The editorship of the MBMJ will become vacant in 2005.

The holder of this rewarding post will work closely with the editorial assistant to produce three issues of the journal each year and will have the opportunity to develop it in their own style.

Anyone interested in this post should contact Peter Dyer (01524 583314) who would be delighted to discuss what is involved in the role. 